\title{
Balneotherapy in Medicine: A Review
}

\author{
Ali NASERMOADDELI ${ }^{1}$ and Sadanobu KAGAMIMORI ${ }^{1}$ \\ ${ }^{I}$ Department of Welfare Promotion and Epidemiology, Toyama Medical and Pharmaceutical University, Toyama, Japan
}

\begin{abstract}
Bathing in water (balneotherapy or spa therapy) has been frequently and widely used in classical medicine as a cure for diseases. This paper reviews the present literature on the use of balneotherapy in dermatologic, chronic musculoskeletal (inflammatory and non-inflammatory), metabolic and psychological conditions.

We performed a systematic review on related papers appearing in the Medline and Cochrane Library database from 1966 to 2003 that included randomized controlled and non-randomized clinical trials using balneotherapy. We also determined to reflect where possible the chemical compositions of spas.

The major dermatologic and musculoskeletal diseases that are frequently treated by balneotherapy with a remarkable rate of success are atopic dermatitis, psoriasis, rheumatoid arthritis (RA), ankylosing spondylitis, osteoarthritis and low back pain. Moreover, the effects of spa therapy on several metabolic conditions are discussed. The mechanisms by which broad spectrums of diseases respond to spa therapy probably incorporate chemical, thermal and mechanical effects.

The importance of balneotherapy either alone or as complement to other therapies should be considered after, or accompanying, orthodox medical treatments.
\end{abstract}

Key words: spa therapy, balneotherapy, review

\section{Introduction}

Over the past decades, a re-assessment of the use of mineral water for the treatment of several diseases has taken place around the world (1). Many rheumatologists and dermatologists now acknowledge the medical significance of bathing. The term balneotherapy comes from the latin balneum (bath). The term is classically used for bathing in thermal or mineral waters. Bathing is usually combined with other treatments, such as physical exercise, hydrotherapy, and mud packs.

Thousands of health resort areas have developed around these hot springs. Spa resorts are differentiated according to their location (sea side, mountain area) and the chemical composition of their mineral water. They are also classified as being low mineralized $(0.6-2 \mathrm{~g} / \mathrm{l})$, mildly mineralized $(>2-10 \mathrm{~g} / \mathrm{l})$ or highly mineralized $(>10 \mathrm{~g} / \mathrm{l})$. Water temperature is described as

Received Jan. 19, 2005/Accepted Apr. 8, 2005 Reprint requests to: Ali NASERMOADDELI

Department of Welfare Promotion and Epidemiology, Faculty of Medicine, Toyama Medical and Pharmaceutical University, 2630 Sugitani, Toyama 930-0194, Japan

TEL: +81(76)434-7274, FAX: +81(76)434-5022

E-mail:moaddeli@ms.toyama-mpu.ac.jp being cold $\left(<20^{\circ} \mathrm{C}\right)$, hypothermal $\left(20-30^{\circ} \mathrm{C}\right)$, thermal $(>30$ $\left.40^{\circ} \mathrm{C}\right)$; or hyperthermal $\left(>40^{\circ} \mathrm{C}\right)(2)$.

Absorption of minerals through the skin seems to be limited. The dermatological therapeutic effect would therefore appear to lie in a local interaction between the mineral water and the structure of the skin surface.

The effects of spa therapy can be divided into three categories: mechanical, thermal and chemical.

\section{Mechanical effects}

Immersion allows the patient to mobilize joints and strengthen muscles with minimal discomfort. This hydrostatic effect is increased when the water is more concentrated. Hydrostatic pressure also causes displacement of fluids from the extremities to the trunk, thus causing hemodilution and increased diuresis. It has been shown that immersion for 1 hour increases water excretion by about $50 \%$ (3).

\section{Thermal effects}

The hot water causes superficial vasodilation and it has been shown to reduce vascular spasm and stasis in the nail bed and conjunctiva (4). The in vivo proliferative response of human peripheral blood lymphocytes to phytohemagglutinin and concanavalin A was enhanced markedly when cultured at 
Table 1 Balneotherapy in patients with dermatologic disorders

\begin{tabular}{|c|c|c|c|c|c|c|}
\hline Disease & Authors & Mode of therapy & $\mathrm{n}$ & $\begin{array}{l}\text { Treatment } \\
\text { duration }\end{array}$ & Efficacy & $\begin{array}{l}\text { *Evidence (Design } \\
\text { and journal type) }\end{array}$ \\
\hline \multirow[t]{2}{*}{ Atopic dermatitis } & $\begin{array}{l}\text { Kubota et al. } \\
(8)\end{array}$ & $\begin{array}{l}\text { Acidic hot-spring bath } \\
\text { pH: } 2.0 \text { plus } \mathrm{Mn} 1.4 \mathrm{mg} / 1 \text {, } \\
\text { I } 0.3 \mathrm{mg} / 1\end{array}$ & 70 & $\begin{array}{l}\text { Median of } \\
2 \text { months }\end{array}$ & $\begin{array}{l}\text { Significant clearing of skin lesions and } \\
\text { reduction in itch }\end{array}$ & $\mathrm{B}(\mathrm{B})$ \\
\hline & Shani et al. (9) & $\begin{array}{l}\text { Balneotherapy in the Dead } \\
\text { Sea }\end{array}$ & 1408 & 4 to 6 weeks & $\begin{array}{l}\text { Complete clearance of lesions in } 90 \% \\
\text { of patients }\end{array}$ & $\mathrm{A}(\mathrm{B})$ \\
\hline \multirow[t]{3}{*}{ Psoriasis } & $\begin{array}{l}\text { Halvey et al. } \\
\text { (11) }\end{array}$ & Dead Sea balneotherapy & 25 & 3 weeks & $\begin{array}{l}\text { Mild improvement comparing to those } \\
\text { treated with common salts bath }\end{array}$ & $\mathrm{B}(\mathrm{A})$ \\
\hline & $\begin{array}{l}\text { Leaute-labreze } \\
\text { et al. (12) }\end{array}$ & $\begin{array}{l}\text { Saline water balneotherapy } \\
\text { (sodium concentration, } \\
250 \mathrm{~g} / \mathrm{l} \text {; magnesium, } \\
980 \mathrm{mg} / \mathrm{l} \text { ) }\end{array}$ & 71 & 3 weeks & $\begin{array}{l}\text { Minor therapeutic effects with saline } \\
\text { spa water alone, and no beneficial effect } \\
\text { of bathing to enhance phototherapy }\end{array}$ & $\mathrm{C}(\mathrm{A})$ \\
\hline & $\begin{array}{l}\text { Pinton et al. } \\
\text { (18) }\end{array}$ & $\begin{array}{l}\text { Immersion and drinking } \\
\text { selenium rich spa }(70 \mu \mathrm{g} / \mathrm{l})\end{array}$ & 92 & 3 weeks & Improvement in psoriatic plaques & $\mathrm{A}(\mathrm{B})$ \\
\hline $\begin{array}{l}\text { Cutaneous } \\
\text { microcirculation }\end{array}$ & $\begin{array}{l}\text { Hartmann et al. } \\
\text { (15) }\end{array}$ & $\begin{array}{l}\text { Balneotherapy with } \mathrm{CO}_{2} \\
(1200 \mathrm{mg} / \mathrm{kg} \text { water) water }\end{array}$ & 18 & 20 minutes & $\begin{array}{l}\text { Cutaneous vasodilation and increased } \\
\text { oxygen utilization }\end{array}$ & $\mathrm{A}(\mathrm{A})$ \\
\hline
\end{tabular}

* Evidence. A: effective, B: probably effective, C: may not be effective.

Design and journal type: A: Randomized clinical trial (RCT) in a major journal, a: RCT in a non-major journal, B: non-randomized clinical study in a major journal, b: non-randomized clinical study in a non-major journal.

$40^{\circ} \mathrm{C}$ compared with the conventional temperature of $37^{\circ} \mathrm{C}(5)$.

\section{Chemical effects}

The solutes or additives in spa water act primarily on the skin, but there is no doubt that under certain conditions resorption of minerals is possible. The composition and physical properties of various spa waters vary. They are salty, sulfurous, bicarbonated, carbonic, radon-rich, selenium-rich, arsenical and ferruginous, etc. It is still not clear which elements are essential and what is the ideal concentration of each element in order to attain an optimal response to treatment.

In this report, we screened published papers from 1966 to 2003 for randomized controlled trials (RCT) and nonrandomized clinical studies of balneotherapy on dermatological, chronic musculoskeletal (inflammatory and non-inflammatory), metabolic and psychological conditions. Key words in the studies were: balneotherapy, spa therapy, RCT and clinical trials. To perform an adequate assessment the language of the publications had to be mainly English. Of the studies not written in English, those with an English abstract that had sufficient information about the study design were selected for this review. We also provided where possible the chemical compositions of the spas. Based on the results and design of each study, and the journal in which the paper published, we classified each study under the following criteria: Evidence; A: effective, B: probably effective, C: may not be effective. Journal type and design; A: RCT in a major journal, a: RCT in a non-major journal, B: non-randomized clinical study in a major journal, b: non-randomized clinical study in a non-major journal. The summarized effects of balneotherapy are shown in Tables 1 to 5.

\section{Dermatologic effects}

Inoue et al. (6) reported that balneotherapy using Kusatsu hot spring water (Japan) is useful for controlling the skin symptoms of acute flares/exacerbations of refractory cases of atopic dermatitis. It is now widely accepted that patients with atopic dermatitis are prone to cutaneous Staphylococcus aureus (S. aureus) infection during phases of acute exacerbation and also an increased density of S. aureus is found to correlate well with the severity of skin manifestations $(7,8)$. It has been demonstrated that $\mathrm{S}$. aureus on the skin surface decreased in number or disappeared after Kusatsu balneotherapy (6). The bactericidal activity of hot spring water was expressed by manganese and iodide ions in acidic conditions. Balneotherapy using acidic hot-spring water (Kusatsu, Japan) was shown to be useful for controlling the skin symptoms of acute flares of refractory cases of atopic dermatitis in comparison to a hot plain-water shower (8).

The Dead Sea is a famous place for its balneologic properties and its effects, especially on ailments of dermatologic and rheumatologic origin. The Dead Sea has a salt content of about $320 \mathrm{~g} / \mathrm{l}$, of which potassium chloride, magnesium chloride, calcium chloride and sodium chloride are the major components. The average mineral salt contents $(\mathrm{g} / \mathrm{l})$ are as follows: sodium, 5.44; potassium, 4.16; calcium, 65.28; magnesium, 15.69; chloride, 24.96; sulfate, 24.96 and carbonate, 74.24. Total concentration of salt and minerals are $32 \%$, compared to a total concentration of $3 \%$ in the ocean (2). Two studies provided evidence for the therapeutic potential of Dead Sea spa therapy for atopic dermatitis $(9,10)$. Complete clearance of lesions was recorded in $90 \%$ of 1408 patients after 4 to 6 weeks therapy at the Dead Sea area. A reduction in itching was recorded during the first week of stay at the Dead Sea area. The percentage of patients who improved during the spring and summer (91\%) was higher than in the autumn (86\%) and winter (74\%) (9). Giryes et al. (10) reported the efficacy of Dead Sea climatotherapy for atopic dermatitis in a non-published study. The climatotherapy regimen consisted of daily sun exposure (maximum, 34 hours a day), bathing in Dead Sea water (20 minutes twice a day) and free application of emollients. Acute exacerbation of 
atopic dermatitis must first be given specific pharmacologic treatment, however, bathing can prepare the skin for the application of moisturizers. Rest and the healthy environment provided by spas can also be positive factor in healing atopic dermatitis.

A prospective, double blind, controlled study (11) evaluated the therapeutic effect of Dead Sea salts in patients with psoriasis. Twenty-five patients with psoriasis vulgaris were randomly allocated to 2 groups treated with either Dead Sea salt baths or common salt baths. After 3 weeks of treatment, mild improvement was observed in patients treated with Dead Sea salts compared with those treated with common salts. However, saline spa water alone at Salies de Bearn in France (sodium concentration, $250 \mathrm{~g} / \mathrm{l}$; magnesium, $980 \mathrm{mg} / \mathrm{l}$ ) was reported to have a minor therapeutic effect on psoriasis compared with UVB exposure in an RCT on 90 patients (12).

Acne vulgaris is another dermatologic disease that benefits from balneotherapy. A non-randomized clinical study of 86 patients treated for acne vulgaris in the Dead Sea area showed a significant improvement manifested by a reduced number of comedones and pustules (9).

Sulfur-rich spas attract special interest for their dermatologic effects. The sulfur that penetrates the skin is oxidized and evokes various physiologic responses in the skin, such as vasodilation in the microcirculation, an analgesic influence on the pain receptors, and inhibition of the immune response. Sulfur also interacts with oxygen radicals in the deeper layers of the epidermis, producing sulfur and disulfur hydrogen, which may be transformed into pentathionic acid, and this may be the source of the antibactericidal and antifungal activity of sulfur water (2). The therapeutic action of sulfur water is related mainly to sulfur's keratolytic effect, resulting in peeling (13).

Schempp et al. (14) demonstrated in both in vivo (a $5 \%$ concentration of $\mathrm{MgCl}_{2}$ ) and in vitro (a $1 \%$ concentration of $\mathrm{MgCl}_{2}$ ) studies that magnesium ions specifically inhibit the antigen-presenting capacity of Langerhans cells and may thus contribute to the efficacy of magnesium-rich spa water in the treatment of inflammatory skin diseases.

Therapeutic activities of $\mathrm{CO}_{2}$ water baths $(700-1300 \mathrm{mg}$ $\mathrm{CO}_{2}$ per kg water) are explained by a synergism between hydrostatic pressure and the chemical properties of carbon dioxide that acts directly on the blood vessels of the skin, causing vasodilation and increased oxygen utilization (15).

Balneotherapy with arsenical-ferruginose (no data on concentrations) water from the spa at Terme di Levico (Italy) showed effectiveness in the treatment of cervico-vaginitis $(\mathrm{n}=20)$ in comparison to placebo suppositories $(\mathrm{n}=10)$. Both clinical signs and symptoms were reduced in the intervention group with good tolerability (16).

Apart from immersion, drinking spa water has also been investigated for treatment of dermatologic conditions. Drinking of low-salt Avene (France) spring water (sodium, $4.9 \mathrm{mg} / \mathrm{l}$; magnesium, $22.5 \mathrm{mg} / \mathrm{l}$; calcium, $44.3 \mathrm{mg} / \mathrm{l}$; bicarbonate, $234.8 \mathrm{mg} / \mathrm{l}$ ) for a period of 18 days normalized the intestinal permeability in patients with atopic dermatitis (17). Drinking and immersion in a selenium-rich spa water (selenate $70 \mu \mathrm{g} / \mathrm{l}$ ) for three weeks at the care center of La Roche-Posay (France) demonstrated an improvement in patients with psoriasis (18). Patients who responded to treatment had a significant increase in their plasma selenium level. In patients with psoriasis, inflammatory reactions in the skin may lead to an increased loss of selenium (18).

\section{Chronic musculoskeletal effects}

Balneotherapy has been practiced for centuries in the management of chronic musculoskeletal diseases. It is based on the indigenous natural remedies of the spas, such as thermal and mineral water and gases $\left(\mathrm{CO}_{2}\right.$, radon). The net beneficial effect of balneotherapy on musculoskeletal diseases is probably a result of mechanical, thermal and chemical effects.

Table 2 Balneotherapy in patients with chronic inflammatory musculoskeletal diseases

\begin{tabular}{|c|c|c|c|c|c|c|}
\hline Disease & Authors & Mode of therapy & $\mathrm{n}$ & $\begin{array}{l}\text { Treatment } \\
\text { duration }\end{array}$ & Efficacy & $\begin{array}{l}\text { *Evidence (Design } \\
\text { and journal type) }\end{array}$ \\
\hline \multirow[t]{4}{*}{$\begin{array}{l}\text { Rheumatoid } \\
\text { arthritis }\end{array}$} & $\begin{array}{l}\text { Sukenik et al. } \\
(19)\end{array}$ & $\begin{array}{l}\text { Sulfur baths, mud packs and } \\
\text { combination }\end{array}$ & 40 & 2 weeks & $\begin{array}{l}\text { Improvement in clinical indices up to } \\
3 \text { months }\end{array}$ & $\mathrm{A}(\mathrm{A})$ \\
\hline & $\begin{array}{l}\text { Elkayam et al. } \\
(20)\end{array}$ & $\begin{array}{l}\text { Mineral water baths and } \\
\text { mud packs (rich in sodium } \\
\text { chloride and sulfate) }\end{array}$ & 41 & 2 weeks & $\begin{array}{l}\text { Temporary improvement in clinical } \\
\text { indices }\end{array}$ & $\mathrm{A}(\mathrm{A})$ \\
\hline & $\begin{array}{l}\text { Sukenik et al. } \\
(21)\end{array}$ & $\begin{array}{l}\text { Dead Sea, sulfur bath or } \\
\text { combination }\end{array}$ & 36 & 3 months & $\begin{array}{l}\text { Improvement in clinical indices in all } \\
\text { three intervention groups }\end{array}$ & $\mathrm{A}(\mathrm{A})$ \\
\hline & $\begin{array}{l}\text { Franke et al. } \\
(23)\end{array}$ & $\begin{array}{l}\text { Combined radon } \\
(1.3 \mathrm{KBq} / \mathrm{l}) \text { carbon dioxide } \\
(1.6 \mathrm{~g} / \mathrm{l}) \mathrm{spa}\end{array}$ & 60 & 4 weeks & $\begin{array}{l}\text { Lower pain intensity after } 6 \text { months } \\
\text { comparing to taking only a carbon } \\
\text { dioxide bath }\end{array}$ & B (a) \\
\hline \multirow[t]{2}{*}{$\begin{array}{l}\text { Ankylosing } \\
\text { spondylitis }\end{array}$} & $\begin{array}{l}\text { Tubergen et al. } \\
\text { (24) }\end{array}$ & $\begin{array}{l}\text { Combination of spa-exercise } \\
\text { therapy }\end{array}$ & 120 & 3 weeks & $\begin{array}{l}\text { Improvement in clinical indices up to } \\
40 \text { weeks }\end{array}$ & $\mathrm{A}(\mathrm{A})$ \\
\hline & $\begin{array}{l}\text { Tishler et al. } \\
(25)\end{array}$ & $\begin{array}{l}\text { Combination of hot mineral } \\
\text { baths }\left(38^{\circ} \mathrm{C}\right) \text { and mud packs } \\
\left(45^{\circ} \mathrm{C}\right)\end{array}$ & 14 & 2 weeks & $\begin{array}{l}\text { Improvement in morning stiffness and } \\
\text { overall well-being }\end{array}$ & $\mathrm{B}(\mathrm{B})$ \\
\hline Fibromyalgia & $\begin{array}{l}\text { Buskila et al. } \\
(27)\end{array}$ & Sulfur baths $(2000 \mathrm{mg} / \mathrm{l})$ & 48 & 10 days & $\begin{array}{l}\text { Improvement in clinical indices up to } \\
3 \text { months }\end{array}$ & $\mathrm{A}(\mathrm{A})$ \\
\hline
\end{tabular}

\footnotetext{
* For details see Table 1 caption.
} 


\section{Inflammatory diseases}

Sukenik et al. (19) reported from an RCT that a two-week period of therapy with sulfur baths or mud packs (no data on mineral concentration), alone or in combination was effective in the treatment of patients with RA. Statistically significant improvements in most clinical indices were observed for a period of up to 3 months in treatment groups. In a similar study Elkayam et al. (20) allocated 41 RA patients at random to 2 groups. One group was treated with a combination of mineral baths (rich in sodium chloride and sulfate (no evidence on concentrations)) and mud packs for 20 minutes in Tiberias (Isreal), while the second group was treated with tap water only. Both groups showed a significant but only temporary improvement. The first group showed significant improvement in grip strength.

Sukenik et al. (21) again reported from a randomized trial that daily bath in the Dead Sea or a daily sulfur bath (no data on sulfur ions concentration), or a combination of both, resulted in improvements in clinical indices such as duration of morning stiffness, grip strength and number of active joints in 36 patients with RA during a 3 month follow-up period, compared to controls.

Radon spa therapy was found to be effective in treatment of RA (22). Sixty patients were grouped to take baths with either radon-carbon dioxide water $(1.3 \mathrm{KBq} / \mathrm{l}$ and $1.6 \mathrm{~g} / \mathrm{l})$ or artificially enriched carbon dioxide water for four weeks. After six months of follow-up, pain intensity remained lower in patients receiving radon-carbon dioxide bath than the other group (23).

Ankylosing spondylitis is another chronic inflammatory disease that benefits from balneotherapy (24-26). In a nonrandomized clinical (25) study 14 patients with ankylosing spondylitis were treated for 2 weeks at a Tiberias spa with a combination of hot mineral water baths $\left(38^{\circ} \mathrm{C}\right)$ and mud packs $\left(45^{\circ} \mathrm{C}\right.$ ) for 20 minutes (no data on mineral concentration). A significant improvement was observed in morning stiffness, finger to floor distance, and overall well-being as assessed by patients and physicians. Combined spa-exercise therapy (Bad Hofgastein, Austria), alongside standard treatment with drugs and weekly group physical therapy, has been shown to be more effective and show favorable cost-effectiveness and cost-utility ratios compared with orthodox treatment alone in patients with ankylosing spondylitis (26).

The beneficiary effect of balneotherapy was also observed in patients with fibromyalgia. Forty-eight patients with fibromyalgia were randomly assigned to a treatment group receiving sulfur baths (sulfur ions concentration of $2000 \mathrm{mg} / \mathrm{l}$ ) for 20 minutes, and a control group with no treatment. All participants stayed for 10 days at a Dead Sea spa. Signs and symptoms of the disease improved in the patients receiving sulfur baths and improvement persisted for 3 months (27).

Although balneotherapy does not replace, but rather complements, conventional drug therapy, it is certainly beneficial in suitable cases.

Table 3 Balneotherapy in patients with chronic non-inflammatory musculoskeletal diseases

\begin{tabular}{|c|c|c|c|c|c|c|}
\hline Disease & Authors & Mode of therapy & $\mathrm{n}$ & $\begin{array}{l}\text { Treatment } \\
\text { duration }\end{array}$ & Efficacy & $\begin{array}{l}\text { *Evidence (Design } \\
\text { and journal type) }\end{array}$ \\
\hline \multirow[t]{4}{*}{ Osteoarthritis } & $\begin{array}{l}\text { Nguyen et al. } \\
(28)\end{array}$ & $\begin{array}{l}\text { Spa therapy at Vichey } \\
\text { (France) }\end{array}$ & 188 & 3 weeks & $\begin{array}{l}\text { Improvements in pain and functional } \\
\text { impairment up to } 6 \text { months }\end{array}$ & $\mathrm{A}(\mathrm{A})$ \\
\hline & $\begin{array}{l}\text { Kovacs et al. } \\
(29)\end{array}$ & $\begin{array}{l}\text { Spa therapy (Solute content } \\
1675 \mathrm{mg} / \mathrm{l} \text { ) mainly sodium } \\
\text { bicarbonate and fluoride) }\end{array}$ & 58 & 15 days & $\begin{array}{l}\text { Improvement in clinical indices } \\
\text { compared to tap water }\end{array}$ & $\mathrm{B}(\mathrm{A})$ \\
\hline & $\begin{array}{l}\text { Green et al. } \\
(30)\end{array}$ & $\begin{array}{l}\text { Hydrotherapy in a deep } \\
\text { pool, and home exercise }\end{array}$ & 47 & 6 weeks & $\begin{array}{l}\text { Improvement of symptoms in both } \\
\text { groups }\end{array}$ & $\mathrm{C}(\mathrm{A})$ \\
\hline & $\begin{array}{l}\text { Wigler et al. } \\
(31)\end{array}$ & Dead Sea balneotherapy & 33 & 2 weeks & $\begin{array}{l}\text { Improvement in clinical indices } \\
\text { specially with the combination of } \\
\text { mineral bath and mud packs }\end{array}$ & $\mathrm{A}(\mathrm{A})$ \\
\hline \multirow[t]{3}{*}{ Low back pain } & \multicolumn{2}{|c|}{$\begin{array}{l}\text { Guillemin et al. Spa therapy (total minerals } \\
\begin{array}{l}\text { (32) } \\
<500 \mathrm{mg} / \mathrm{l}, \text { mainly sulfate } \\
\text { and sodium) with high } \\
\text { pressure under water shower } \\
\left(36^{\circ} \mathrm{C}\right)\end{array}\end{array}$} & 102 & 3 weeks & $\begin{array}{l}\text { Positive short term effectiveness on } \\
\text { chronic pain compared to controls }\end{array}$ & $\mathrm{A}(\mathrm{A})$ \\
\hline & $\begin{array}{l}\text { Constant et al. } \\
\text { (33) }\end{array}$ & $\begin{array}{l}\text { Spa therapy (total minerals } \\
8073 \mathrm{mg} / \mathrm{l} \text {, mixed bicarbon- } \\
\text { ate, chlorine and sodium) } \\
\text { and drug therapy compare } \\
\text { with drug therapy alone }\end{array}$ & 121 & 3 weeks & $\begin{array}{l}\text { Improvements in signs and symptoms } \\
\text { in the combination group }\end{array}$ & $\mathrm{A}(\mathrm{A})$ \\
\hline & $\begin{array}{l}\text { Konard et al. } \\
(34)\end{array}$ & $\begin{array}{l}\text { Balneotherapy (bicarbonate } \\
(445.3 \mathrm{mg} / \mathrm{l}) \text {, sulfate } \\
(109.9 \mathrm{mg} / \mathrm{l}) \text { and calcium } \\
(117.2 \mathrm{mg} / \mathrm{l})) \text {, underwater } \\
\text { massage, underwater } \\
\text { traction bath }\end{array}$ & 158 & 4 weeks & $\begin{array}{l}\text { Reduction of prescription of analgesics } \\
\text { and pain score in all intervention groups }\end{array}$ & B (B) \\
\hline Chronic pain & $\begin{array}{l}\text { Strauss-Blasche } \\
\text { et al. (35) }\end{array}$ & $\begin{array}{l}\text { Balneotherapy with mud } \\
\text { and } \mathrm{CO}_{2} \text { applications }\end{array}$ & 387 & 3 weeks & $\begin{array}{l}\text { Seasonal variation in effectiveness, best } \\
\text { response was between April and June }\end{array}$ & $\mathrm{B}(\mathrm{b})$ \\
\hline
\end{tabular}

\footnotetext{
* For details see Table 1 caption.
} 


\section{Non-inflammatory diseases}

The aim of balneotherapy in musculoskeletal diseases is to improve the range of joint movements, cause muscle strengthening, relieve muscle spasm, maintain or improve functional mobility, and as a consequence to relieve patients' suffering.

Balneotherapy for osteoarthritis provided satisfactory results (28-31). An RCT study was conducted in patients with osteoarthritis of the hip, knee or lumbar spine (28). Treatment was either spa therapy $(n=91)$ of three weeks duration at Vichey (France) (no data on mineral components) or the usual therapy $(n=97)$ at home. Changes in the assessment criteria after a 6 months follow-up period showed improvement in terms of pain, functional impairment and quality of life in the spa group. The effects of thermal water $\left(36^{\circ} \mathrm{C}\right.$ for 30 minutes $)$ from Cserkeszolo (Hungary) were appraised in a randomized, double blind study on 58 patients with osteoarthritis of the knee (29). Balneotherapy was performed with spa water (Solute content of $1675 \mathrm{mg} / \mathrm{l}$ comprised primarily of sodium bicarbonate along with silicic acid $(48 \mathrm{mg} / \mathrm{l})$ and fluoride $(1.8 \mathrm{mg} / \mathrm{l}))$ and tap water. Both groups improved in signs and symptoms, but the magnitude of improvement was significantly greater in patients treated with spa water.

Low back pain is another non-inflammatory musculoskeletal disease that benefits from short and long-term effects of spa therapy $(32,33)$. Constant et al. (33) assessed the overall effectiveness of spa therapy at Saint-Nectaire (France) compared with the usual routine drug therapy in chronic low back pain. In an RCT, 121 patients were allocated to treatment $(n=59)$ and control $(n=62)$ groups. In the treatment group, patients underwent routine drug therapy and spa therapy (total mineral content of $8073 \mathrm{mg} / \mathrm{l}$ of mixed bicarbonate, chlorine and sodium composition) 6 days per week for 3 consecutive weeks. In the control group, patients received routine drug therapy.
After 3 weeks of intervention and 6 months of follow-up, patients in the treatment group had significant improvement in signs and symptoms of the disease and also drug consumption (analgesic and anti-inflammatory).

Three treatments for non-specific lumbar pain: balneotherapy (total mineral concentration of $901 \mathrm{mg} / \mathrm{l}$, mainly bicarbonate, $445.3 \mathrm{mg} / \mathrm{l}$; sulfate, $109.9 \mathrm{mg} / \mathrm{l}$ and calcium, $117.2 \mathrm{mg} / \mathrm{l}$ electrolytes), underwater traction bath and underwater massage were assessed in a randomized prospective controlled trial in 158 outpatients (34). Each group was treated for 4 weeks and patients were reviewed at the end of this period and at 12 months following entry to the trial. The prescription of analgesics and pain score were significantly reduced in all three treated groups but there was no difference between the three groups. After 1 year, only consumption of analgesics remained significantly lower in the intervention groups than in the control group who received no treatment.

Strauss-Blasche et al. (35) reported seasonal variation in the effects of spa therapy (including mud and $\mathrm{CO}_{2}$ applications) on chronic pain. A total of 387 patients with non-inflammatory chronic pain stayed at a spa in Austria for 3 weeks and received 2-4 treatments per day, including mudpacks, massages, and exercise therapy. In different groups of patients for 2 years, pain was measured at the beginning, end, and 6 weeks after spa therapy. The effect of spa therapy on pain was best between April and June and a medium decrease of pain was more likely between October and November. The magnitude of the seasonal variation was greater for back pain than for joint pain.

The effectiveness of balneotherapy in the management of patients with arthritis is attributed to physiological changes like increased diuresis and hemodilution, as well as biomechanical changes like joint unloading, relaxation and increased muscle function $(4,36,37)$.

Table 4 Balneotherapy in metabolic conditions

\begin{tabular}{|c|c|c|c|c|c|c|}
\hline Condition & Authors & Mode of therapy & $\mathrm{n}$ & $\begin{array}{l}\text { Treatment } \\
\text { duration }\end{array}$ & Efficacy & $\begin{array}{l}\text { *Evidence (Design } \\
\text { and journal type) }\end{array}$ \\
\hline Blood viscosity & $\begin{array}{l}\text { Shirakura et al. } \\
\text { (39) }\end{array}$ & $\begin{array}{l}\text { Whole body bathing in } \\
\text { hyperthermal water }\left(42^{\circ} \mathrm{C} \text { or }\right. \\
\text { higher })\end{array}$ & 7 & $10-15$ minutes & $\begin{array}{l}\text { Marked increase of blood viscosity } \\
\text { and enhancement in the blood } \\
\text { coagulation system }\end{array}$ & $A(b)$ \\
\hline Platelet aggregability & $\begin{array}{l}\text { Ohtsuka et al. } \\
\text { (43) }\end{array}$ & $\begin{array}{l}\text { Hydrotherapy with water } \\
\text { temperature between } 30 \text { to } \\
40^{\circ} \mathrm{C}\end{array}$ & 12 & 4 weeks & $\begin{array}{l}\text { Partial improvement of platelet } \\
\text { gluthatione metabolism }\end{array}$ & $\mathrm{B}(\mathrm{b})$ \\
\hline Beta-thromboglobulin & Take et al. (45) & $\begin{array}{l}\text { Hydrotherapy with water } \\
\text { temperature of } 47 \text { and } 42^{\circ} \mathrm{C}\end{array}$ & 5 & 10 minutes & $\begin{array}{l}\text { Plasma beta-thromboglobulin } \\
\text { increased with } 47^{\circ} \mathrm{C} \text { bathing }\end{array}$ & B (a) \\
\hline Bone structure & Ay et al. (48) & $\begin{array}{l}\text { Aerobic exercise in a spa } \\
\text { resort pool with water } \\
\text { temperature of } 29-30^{\circ} \mathrm{C}\end{array}$ & 41 & 6 months & Anabolic effects on the heel bone & $\mathrm{A}(\mathrm{A})$ \\
\hline Plasma lipids & $\begin{array}{l}\text { Strauss-Blasche } \\
\text { et al. (49) }\end{array}$ & $\begin{array}{l}\text { Spa therapy }\left(\mathrm{CO}_{2}\right) \text {, exercise } \\
\text { therapy, and dietary measures }\end{array}$ & 395 & 3 weeks & $\begin{array}{l}\text { Mild decrease in total cholesterol, } \\
\text { HDL cholesterol and LDL cholesterol }\end{array}$ & $\mathrm{B}(\mathrm{b})$ \\
\hline Stress hormones & $\begin{array}{l}\text { Kuczera et al. } \\
(51)\end{array}$ & $\begin{array}{l}\text { Spa therapy at Wysowa } \\
\text { (Poland) }\end{array}$ & 175 & 20 days & $\begin{array}{l}\text { Increase of plasma concentration of } \\
\text { ACTH, cortisol, growth hormone } \\
\text { and prolactin }\end{array}$ & $A(b)$ \\
\hline Plasma homocysteine & $\begin{array}{l}\text { Leibetseder et } \\
\text { al. (52) }\end{array}$ & $\begin{array}{l}\text { Spa therapy with Sulfur as } \\
\text { the main mineral }(7.3 \mathrm{mg} / \mathrm{l})\end{array}$ & 40 & 3 weeks & $\begin{array}{l}\text { Reduction of plasma homocysteine } \\
\text { in sulfur bath group compare to } \\
\text { controls }\end{array}$ & $\mathrm{A}(\mathrm{A})$ \\
\hline
\end{tabular}

\footnotetext{
* For details see Table 1 caption.
} 


\section{Metabolic effects}

Water temperature has an important role for the metabolic effects of balneotherapy. In Japan, the most outstanding feature of balneotherapy is repeated whole body immersion in hot water $\left(42^{\circ} \mathrm{C}\right.$ or higher). Ohtsuka et al. (38) reported that immersion in water at $42^{\circ} \mathrm{C}$ for 10 minutes resulted in oxidative stress by increasing the levels of lipid peroxides and decreasing the activities of glutathione peroxides in erythrocytes. Moreover, whole body bathing in hot water $\left(42^{\circ} \mathrm{C}\right.$ or higher for 10 15 minutes) is reported to induce a marked increase of blood viscosity and an enhancement of the blood coagulation system (39). However, drinking of electrolyte water containing (meq/l) sodium, 21; potassium, 7; calcium, 1 and chloride, 18.5 at midnight was associated with a decrease in blood viscosity from midnight to $8 \mathrm{AM}(40)$.

Platelet glutathione metabolism is impaired among patients with diabetes mellitus and coronary heart disease, in which platelet aggregability is elevated $(41,42)$. Ohtsuka et al. (43) reported from a clinical controlled trial on 12 type II diabetic patients that four weeks of twice or thrice daily balneotherapy at a spa in Hokkaido (Japan), with the water temperature between 39 to $40^{\circ} \mathrm{C}$ (no data on mineral compositions), resulted in partial improvement of platelet glutathione metabolism. They concluded that balneotherapy was beneficial for patients whose platelet antioxidative defense system is damaged, such as those with diabetes mellitus and coronary heart disease. However, immersion in hot water $\left(42^{\circ} \mathrm{C}\right.$ or higher $)$ for 10 minutes was reported to cause an increase in the activity of erythrocyte aldose reductase, which has a positive correlation with hemoglobin Alc (44). The change in erythrocyte aldose reductase activity might aggravate diabetic complications, and therefore, body exposure to hot environmental conditions is better avoided for diabetic patients.

To determine the involvement of activated platelets in the frequent thrombosis after hot hot-spring bathing, Take et al. (45) found that plasma levels of beta-thromboglobulin began to rise at 5 minutes and elevated significantly 10 minutes after the start of $47^{\circ} \mathrm{C}$ hot spring bathing at Kusatsu (Japan). This effect was not observed with bathing at $42^{\circ} \mathrm{C}$. Concentrations of beta-thromboglobulin were significantly correlated with intimamedia thickness of the common carotid artery (46). Acute hyperthermal stress due to hot hot-spring water may also decrease the fibrinolytic capacity, leading to the occurrence of thrombotic events (47).

Some spa resorts have aerobic exercise facilities. Aerobic exercise in the Ataturk spa resort (Turkey) for 6 months with the water temperature of $29-30^{\circ} \mathrm{C}$ was determined to have positive anabolic effects on the bone of 41 postmenopausal, sedentary subjects, in comparison to control group who were instructed to maintain their sedentary lifestyle for the duration of the study (48).

Spa therapy has also been studied for its possible lipidlowering effect. Strauss-Blasche et al. (49) reported that a 3week spa therapy (consisting of mud packs, $\mathrm{CO}_{2}$ baths and massage and exercise therapy) at Bad Tatzmannsdorf (Austria) in 395 patients with musculoskeletal chronic pain over 2 years was associated with a mild decrease of total cholesterol, HDL cholesterol and LDL cholesterol.

Kuczera et al. (50) found that spa therapy (no data on mineral components) in Wysowa (Poland) for 20 days was associated with a significant increase of plasma erythropoietin, iron, ferritin and saturation of transferrin with iron plus an increase in the concentration of stress reaction hormones (51).

Leibetseder et al. (52) provided evidence that sulfur baths $\left(\mathrm{S}^{-2}\right.$ concentration of $\left.7.3 \mathrm{mg} / \mathrm{l}\right)$ exert beneficial effects on plasma homocysteine. Plasma homocysteine is a risk factor for cardiovascular diseases (53). Forty subjects were randomized into two equal groups, a treatment group who received stationary spa therapy plus daily sulfur baths, and a control group who received spa therapy alone. Plasma homocysteine was significantly reduced in the sulfur bath group and rose insignificantly in the control group after three weeks stay at the spa resort. The researchers did not find any significant change in the urinary levels of 8-hydroxydeoxy Guanosine in both groups (52). Studies on rats provided evidence of an increase in heat-shock protein expression after bathing for 15 minutes in $41^{\circ} \mathrm{C}$ hot water for 4 weeks $(54,55)$. Heat-shock proteins are known as important endogenous cell-protective proteins induced in response to a wide variety of stresses $(56,57)$.

\section{Psychological effects}

A few studies addressed the psychological effects of balneotherapy. Steam baths, saunas and whirlpools are standard equipment in many spa resorts, with the main objective being to relax and strengthen the body and mind, and to prevent development of disease. A medium (3-month) to long term (6-month) intervention at a spa resort with bathing and health education resulted in less psychological tension and self-rated depression, and more vigorousness, among a group of middle-aged and elderly women $(58,59)$.

Table 5 Balneotherapy in psychological conditions

\begin{tabular}{|c|c|c|c|c|c|c|}
\hline Condition & Authors & Mode of therapy & $\mathrm{n}$ & $\begin{array}{l}\text { Treatment } \\
\text { duration }\end{array}$ & Efficacy & $\begin{array}{l}\text { *Evidence (Design } \\
\text { and journal type) }\end{array}$ \\
\hline $\begin{array}{l}\text { Psychological } \\
\text { tension }\end{array}$ & $\begin{array}{l}\text { Kamioka et al. } \\
(58)\end{array}$ & $\begin{array}{l}\text { Once a week balneotherapy } \\
\left(41.5^{\circ} \mathrm{C}\right) \text { with lifestyle edu- } \\
\text { cation and physical exercise }\end{array}$ & 56 & 3 months & $\begin{array}{l}\text { Less psychological tension in the } \\
\text { intervention group than controls }\end{array}$ & B (a) \\
\hline $\begin{array}{l}\text { Self-rated } \\
\text { depression and } \\
\text { vigorousness }\end{array}$ & $\begin{array}{l}\text { Kamioka et al. } \\
\text { (59) }\end{array}$ & $\begin{array}{l}\text { Once a week balneotherapy } \\
\left(41.5^{\circ} \mathrm{C}\right) \text { with lifestyle edu- } \\
\text { cation and physical exercise }\end{array}$ & 56 & 6 months & $\begin{array}{l}\text { Less self-rated depression and increas- } \\
\text { ing vigorousness in the intervention } \\
\text { group than controls }\end{array}$ & B (a) \\
\hline
\end{tabular}

* For details see Table 1 caption. 
Rest is an important element in a spa resort treatment. The physical and emotional distance from the stress and concerns of daily life and worries over livelihood could be beneficial in reducing daily stress. Stress reduction has been shown to reduce disease activity by its effect on the soluble interleukin-2 receptor level in RA (60).

General contraindications for balneotherapy should also be considered. These contraindications include severe psychiatric conditions, acute alcoholic states, epilepsy, cardiac dysrhythmias, inadequate balance, severe varicose veins, open wounds and hypersensitivity to mineral baths (61). Furthermore, hyperthermic immersion might produce potentially dangerous cardiovascular effects, such as ectopic beats and excessive tachycardia (62).

\section{Conclusion}

Although there is a tendency to publish statistically significant findings and there is a lack of access to many nonsignificant studies, existing data support the beneficial effects of spa therapy on several diseases and conditions. Besides any

\section{References}

( 1 ) Routh HB, Bhowmik KR, Parish LC, Witkowski JA. Balneology, mineral water, and spas in historical perspective. Clin Dermatol. 1996; 14: 551-554.

( 2 ) Matz H, Orion E, Wolf R. Balneotherapy in dermatology. Dermatol Ther. 2003; 16: 132-140.

( 3 ) O'Hare JP, Heywood A, Summerhayes C, Lunn G, Evans JM, Walters G, Corrall RJ, Dieppe PA. Observations on the effect of immersion in bath spa water. BMJ. 1985; 291: 1747-1751.

( 4 ) Adler E. Some clinical experience with the springs at Zohar on the shore of the Dead sea. Isr J Med Sci. 1961; 20: 304308.

( 5 ) Smith JB, Knowlton RP, Agarwal SS. Human lymphocyte responses are enhanced by culture at $40^{\circ} \mathrm{C}$. J Immunol. 1978; 121: 691-694.

(6) Inoue $\mathrm{T}$, Inoue $\mathrm{S}$, Kubota $\mathrm{K}$. Bactericidal activity of manganese and iodide ions against Staphylococcus aureus: a possible treatment for acute atopic dermatitis. Acta Derm Venereol. 1999; 79: 360-362.

( 7 ) Svejgaard E. The role of microorganisms in atopic dermatitis. Semin Dermatol. 1990; 9: 255-261.

( 8 ) Kubota K, Machida I, Tamura K, Take H, Kurabayashi H, Akiba T, Tamura J. Treatment of refractory cases of atopic dermatitis with acidic hot spring. Acta Derm Venereol. (Stockh) 1997; 77: 452-454.

(9) Shani J, Seidl V, Hristakieva E, Stanimirovic A, Burdo A, Harari M. Indications, contraindications and possible sideeffects of climatotherapy at the Dead sea. Int J Dermatol. 1997; 36: 481-492.

(10) Giryes H, Friger M, Sarov B. Treatment of atopic dermatitis in the Dead sea area: biology and therapy of inflammatory skin diseases. Presented at: International Symposium at the Dead Sea; November 2-6, 1997; Dead Sea, Isreal.

(11) Halvey S, Giryes H, Friger M, Sukenik S. Dead sea bath salt for the treatment of psoriasis vulgaris: a double-blind specific effect of any natural waters, a proper regimen of treatment and rehabilitation with physiotherapy and hydrotherapy in an atmosphere free from stress will undoubtedly help many patients. In interpretation of the findings, the methodological aspects for each study should be taken into consideration. Can the tap water be adequately disguised? Can immersion be organized in a double-blind fashion? Can the wider aspects of climatotherapy be controlled? In addition, some other important questions should also be answered: Could the positive findings have resulted from patient expectations? How long do the positive effects persist? Were the benefits worth the costs? It is not clearly recognizable whether the improvements seen were due to the direct effect of spas or from the resort stay. Since the temperature and chemical compositions of each spa is a characteristic of that spa resort, extrapolating the results to other spa resorts should be done cautiously.

Most of the studies reported in this review were conducted on a small number of subjects. With such a smaller number, clinically relevant effects might be missed. Performing randomized studies using a larger study population is recommended so that statistical significance comes close to clinical relevance. controlled study. J Eur Acad Dermatol. 1997; 9: 237-242.

(12) Leaute-labreze C, Saillour F, Chene G, Cazenave C, LuxeyBellocq ML, Sanciaume C, Toussaint JF, Taieb A. Saline spa water or combined water and UV-B for psoriasis vs conventional UV-B. Arch Dermatol. 2001; 137: 1035-1039.

(13) Hjorth N. Traditional topical treatment of acne. Acta Derm Venereol. (Stockh) 1980; 89: 53-55.

(14) Schempp CM, Dittmar HC, Hummler D. Magnesium ions inhibit the antigen-presenting function of human epidermal Langerhans cells in vivo and in vitro. Involvement of ATPase, HLA-DR, B7 molecules, and cytokines. J Invest Dermatol. 2000; 115: 680-686.

(15) Hartmann BR, Bassenge E, Pittler M. Effect of carbon dioxide-enriched water and fresh water on the cutaneous microcirculation and oxygen tension in the skin of the foot. Angiology. 1997; 48: 337-343.

(16) Danesino V. Balneotherapy with arsenical-ferruginous water in chronic cervico-vaginitis. A case-control study. Minerva Ginecol. 2001; 53: 63-69. (Article in Italian)

(17) Dupuy P, Casse M, Andre F, Dhivert-Donnadieu H, Pinton J, Hernandez-Pion C. Low-salt water reduces intestinal permeability in atopic patients. Dermatology. 1999; 198: 153-155.

(18) Pinton J, Friden H, Kettaneh-Wold N, Wold S. Clinical and biological effects of balneotherapy with selenium-rich spa water in patients with psoriasis vulgaris. Br J Dermatol. 1995; 133: 344-347.

(19) Sukenik S, Buskila D, Neumann L, Kleiner-Baumgarten A, Zimlichman RS, Horowitz J. Sulfur bath and mud pack treatment for rheumatoid arthritis at the Dead sea area. Ann Rheum Dis. 1990; 49: 99-102.

(20) Elkayam O, Wigler I, Tishler M. Effect of spa therapy in Tiberias on patients with rheumatoid arthritis and osteoarthritis. J Rheumatol. 1991; 18: 1799-1803.

(21) Sukenik S, Neumann L, Flusser D. Balneotherapy for rheu- 
matoid arthritis at the Dead sea. Isr J Med Sci. 1995; 31:210 214.

(22) Kolarz G. Critical approach to spa treatment in rheumatic diseases. Rheumatol Eur. 1995; 24: 144-146.

(23) Franke A, Reiner L, Pratzel HG, Franke T, Resch KL. Longterm efficacy of radon spa therapy in rheumatoid arthritis- a randomized, sham-controlled study and follow-up. Rheumatology. 2000; 39: 894-902.

(24) Tubergen A, Landewe R, Heijde D, Hidding A, Wolter N, Asscher M, Falkenbach A, Ekkehard G, Goei The H, Linden $\mathrm{S}$. Combined spa-exercise therapy is effective in patients with ankylosing spondylitis: a randomized controlled trial. Arthritis Care Res. 2001; 45: 430-438.

(25) Tishler M, Brostovski Y, Yaron M. Effects of spa therapy in Tiberias on patients with ankylosing spondylitis. Clin Rheumatol. 1995; 14: 21-25.

(26) Tubergen A, Boonen A, Landewe R, Rutten-Van Molken M, Heijde D, Hidding A, Linden S. Cost effectiveness of combined spa-exercise therapy in ankylosing spondylitis: a randomized controlled trial. Arthritis Rheum. 2002; 47: 459467.

(27) Buskila D, Abu-Shakra M, Neumann L, Odes L, Shneider E, Flusser D, Sukenik S. Balneotherapy for fibromyalgia at the Dead sea. Rheumatol Int. 2001; 20: 105-108.

(28) Nguyen M, Revel M, Dougados M. Prolonged effects of 3 week therapy in a spa resort on lumbar spine, knee and hip osteoarthritis: follow-up after 6 months: a randomized controlled trial. Br J Rheumatol. 1997; 36: 77-81.

(29) Kovacs I, Bender T. The therapeutic effects of Cserkeszolo thermal water in osteoarthritis of the knee: a double blind, controlled, follow-up study. Rheumatol Int. 2002; 21: 218 221.

(30) Green J, Mckenna F, Redfern EJ, Chamberlain MA. Home exercises are as effective as outpatient hydrotherapy for osteoarthritis of the hip. Br J Rheumatol. 1993; 32: 812-815.

(31) Wigler I, Elkayam O, Paran D. Spa therapy for gonarthrosis: a prospective study. Rheumatol Int. 1995; 15: 65-68.

(32) Guillemin F, Constant F, Collin JF, Boulange M. Short and long-term effect of spa therapy in chronic low-back pain. Br J Rheumatol. 1994; 33: 148-151.

(33) Constant F, Collin JF, Guillemin F, Boulange M. Effectiveness of spa therapy in chronic low back pain: a randomized clinical trial. J Rheumatol. 1995; 22: 1315-1320.

(34) Konard K, Tatrai T, Hunka A. Controlled trial of balneotherapy in treatment of low back pain. Ann Rheum Dis. 1992; 51: $820-822$

(35) Strauss-Blasche G, Ekmekcioglu C, Leibetseder V, Melchart $\mathrm{H}$, Marktl W. Seasonal variation in effect of spa therapy on chronic pain. Chronobiol Int. 2002; 19: 483-495.

(36) Becker BE. The biologic aspects of hydrotherapy. J Back Musculoskeletal Rehabil. 1994; 4: 255-264.

(37) Golland A. Basic hydrotherapy. Physiotherapy. 1981; 67: 258-262.

(38) Ohtsuka Y, Yabunaka N, Fujisawa H, Watanabe I, Agishi Y. Effect of thermal stress on glutathione metabolism in human erythrocytes. Eur J Appl Physiol Occup Physiol. 1994; 68: 87-91.

(39) Shirakura T, Kubota K. Balneotherapy in hematology and immunology. Jpn J Biometeor. 1992; 29: 15-23. (Article in Japanese)
(40) Kurabayashi H, Kubota K, Tamura J, Shirakura T. A glass of water at midnight for possible prevention of cerebral infarction. Stroke. 1991; 22: 1326-1327.

(41) Muruganandam A, Drouillard C, Thibert RJ, Cheung RM-C, Draisey TF, Mutus B. Glutathione metabolic enzyme activities in diabetic platelets as a function of glycemic control. Thromb Res. 1992; 67: 385-397.

(42) Buczynski A, Wachowicz B, Kedziora-Kornatowska K, Tkaczewski W, Kedziora J. Changes in antioxidant enzyme activities, aggregability and malonyldialdehyde concentration in blood platelets from patients with coronary heart disease. Atherosclerosis. 1993; 100: 223-228.

(43) Ohtsuka Y, Yabunaka N, Watanabe I, Noro H, Agishi Y. Balneotherapy and platelet glutathione metabolism in type II diabetic patients. Int J Biometeorol. 1996; 39: 156-159.

(44) Ohtsuka Y, Yabunaka N, Watanabe I, Noro H, Fujisawa H, Agishi Y. Thermal stress and diabetic complications. Int J Biometeorol. 1995; 38: 57-59.

(45) Take H, Kubota K, Tamura K, Kurabayashi H, Shirakura T, Miyawaki S, Kobayashi I. Activation of circulating platelets by hyperthermal stress. Eur J Med Res. 1996; 1: 562-564.

(46) Nomura E, Kohriyama T, Yamaguchi S, Kajikawa H, Nakamura S. Significance of the coagulation and fibrinolytic parameters as predictors for carotid atherosclerosis. Rinsho Shinkeigaku [Clinical Neurology] 1996; 36: 741-745. (Article in Japanese)

(47) Tamura K, Kubota K, Kurabayashi H, Shirakura T. Effects of hyperthermal stress on the fibrinolytic system. Int J Hyperthermia. 1996; 12: 31-36.

(48) Ay A, Yurtkuran M. Evaluation of hormonal response and ultrasonic changes in the heel bone by aquatic exercise in sedentary postmenopausal women. Am J Phys Med Rehabil. 2003; 82: 942-949.

(49) Strauss-Blasche G, Ekmekcioglu C, Leibetseder V, Marktl W. Seasonal variation of lipid-lowering effects of complex spa therapy. Forsch Komplementarmed Klass Naturheilkd. 2003; 10: 78-84.

(50) Kuczera M, Kokot F. The influence of spa therapy on the endocrine system. II. Erythropoietin. Pol Arch Med Wewn. 1996; 95: 21-28. (Article in Polish)

(51) Kuczera M, Kokot F. Effects of spa therapy on the endocrine system. I. Stress reaction hormones. Pol Arch Med Wewn. 1996; 95: 11-20. (Article in Polish)

(52) Leibetseder V, Strauss-Blasche G, Holzer F, Marktl W, Ekmekcioglu C. Improving homocysteine levels through balneotherapy: effects of sulphur baths. Clin Chim Acta. 2004; 343: 105-111.

(53) Ozkan Y, Ozkan B, Simsek B. Plasma total homocysteine and cysteine levels as cardiovascular risk factors in coronary heart disease. Int J Cardiol. 2002; 82: 269-277.

(54) Okada M, Hasebe N, Aizawa Y, Izawa K, Kawabe J, Kikuchi $\mathrm{K}$. Thermal treatment attenuates neointimal thickening with enhanced expression of heat-shock protein 72 and suppression of oxidative stress. Circulation. 2004; 109: 1763-1768.

(55) Yamashita N, Hoshida S, Taniguchi N, Kuzuya T, Hori M. Whole-body hyperthermia provides biphasic cardioprotection against ischemia/reperfusion injury in the rat. Circulation. 1998; 98: 1414-1421.

(56) Benjamin IJ, McMillan DR. Stress (heat shock) proteins molecular chaperones in cardiovascular biology and disease. 
Circ Res. 1998; 83: 117-132.

(57) Latchman DS. Heat shock proteins and cardiac protection. Cardiovasc Res. 2001; 51: 637-646.

(58) Kamioka Y, Okada S, Mutoh Y, Yazaki T. Effectiveness of comprehensive education combining hot spa bathing and lifestyle exercise education. J Jpn Assoc Phys Med Balneol Climatol. 2003; 66: 239-248. (Article in Japanese)

(59) Kamioka H, Nakamura Y, Yazaki T, Uebaba K, Mutoh Y, Okada S, Takahashi M. Effectiveness of comprehensive hot spa bathing and lifestyle education in middle-aged and elderly women: randomized controlled trial of three- and six month interventions. J Jpn Assoc Phys Med Balneol Climatol. 2004;
67: 202-214.

(60) Harrington L, Affleck G, Urrows S, Tennen H, Higgins P, Zautra A, Hoffman S. Temporal covariation of soluble interleukin-2 receptor levels, daily stress, and disease activity in rheumatoid arthritis. Arthritis Rheum. 1993; 36: 199-203.

(61) Halvey S, Sukenik S. Different modalities of spa therapy for skin diseases at the Dead sea area. Arch Dermatol. 1998; 134: 1416-1420.

(62) Turner B, Pennefather J, Edmonds C. Cardiovascular effects of hot water immersion (suicide soup). Med J Aust. 1980; 2: 39-40. 